\title{
Чимаров С.Ю., Косолапов А.Д. \\ Психолого-педагогический анализ миссии и основных направлений воспитания в концептах учения Э. Фромма
}

Санкт-Петербургский университет МВД России (Россия, Санкт-Петербург)

doi: $10.18411 / l j-02-2021-180$

idsp: ljournal-02-2021-180

\section{Аннотация}

В статье представлен анализ отдельных воззрений Э. Фромма, имеющих непосредственное отношение к проблеме воспитания человека. Выявляя ряд сущностных положений некоторых установок данного ученого в контексте обзора зарубежной психолого-педагогической мысли, авторы акцентируют внимание на актуальности гуманизма педагогики, нацеленной на развитие внутреннего мира человека и совершенствование его социального характера, что несомненно должно содействовать углублению гармонии между ценностями каждого человека и общества в целом.

Ключевые слова: воспитание, воспитательная функция, педагогика, психология, образование, человек, социальный характер человека.

\section{Abstract}

The article presents an analysis of individual views of E. Fromm, which are directly related to the problem of human upbringing. Revealing a number of essential provisions of some attitudes of this scientist in the context of a review of foreign psychological and pedagogical thought, the authors focus on the relevance of the humanism of pedagogy aimed at developing a person's inner world and improving his social character, which undoubtedly should contribute to deepening harmony between the values of each person and society in the whole.

Keywords: upbringing, upbringing function, pedagogy, psychology, education, man, social character of man.

Эрих Фромм (1900-1980 гг.)-немецко-американский психолог, философ и родоначальник теории «радикально-гуманистического психоанализа» внес значительный вклад в развитие педагогической науки. По оценке исследователя творчества данного ученого Г.А. Новичковой, актуальность трудов Э. Фромма объясняется самим фактом определения в центр его научных интересов многих проблем человека, связанных с процессами формирования и становления личности, ролью и задачами воспитания и образования [1, с. 57]. Заключив на первое место в системе современного общества подсистему «Человек», Э. Фромм предостерегает от опасности игнорирования человеческой природы и необходимости учета при ее анализе собственных качеств, законов и альтернатив данной подсистемы [4, с. 26].

Исследуя феномен воспитания человека с момента его рождения и в ходе его последующей социализации, Э. Фромм констатирует, что связь человека с внешним миром предопределяет ограничение его свободы и свидетельствует о наличии первичных уз, связывающих человека с его почвой: матерью, племенем, природой, церковью и сословием. Указанные узы: во-nервых, придают человеку ощущение принадлежности к чему-то; во-вторых, гарантируют ему безопасность существования за счет корней в какой-либо почве; в-третьих, являются естественным фактором нормального человеческого развития; в-четвертых, придают индивиду уверенность и способствуют его жизненной ориентации. С наступлением полной индивидуализации человека он освобождается от первичных уз и перед ним встает новая задача, нацеленная как на ориентацию и укоренение в окружающем его мире, так и на поиск 
для себя новых гарантий дальнейшего существования [3, с. 39]. Осваивая окружающий мир посредством собственной деятельности, человек все более углубляется в процесс индивидуализации, ускорение которого сопряжено с процессом воспитания [3, с. 40].

Выявляя подлинную цель воспитания как условия полноценного развития личности, Э. Фромм акцентирует внимание на необходимости развития ее внутренней независимости и индивидуальности. По мысли ученого, воспитание наряду с образованием должно способствовать развитию непосредственности человека и избегать подмены оригинальных психических актов навязанными чувствами, мыслями и желаниями: «оригинальной я считаю не ту идею, которая никогда никому не приходила на ум; важно, что бы она возникла у самого индивида, чтобы она была результатом его собственной психической деятельности, то есть его мыслью» [3, с. 246].

Самостоятельным направлением педагогических воззрений Э. Фромма выступает анализ роли воспитания в решении задачи формирования сочииального характера человека как ключевого момента для понимания общественных процессов и под котором следует понимать общие особенности личности, характеризующие большинство членов конкретной социальной группы суть совокупность черт характера, общую для большинства и возникшую в результате общих переживаний и общего образа жизни [3, с. 280-281].

Актуальность неизменности обращения к теме характера при исследовании сущностных вопросов воспитания Э. Фромм объясняет следующим образом: «синдром характера коренится в определенных формах ориентации индивида, демонстрирующих его отношение к внешнему миру и к себе самому, и является главным источником, питающим личность» [2, с. 82]. Апеллируя к теме формирования социального характера человека, Э. Фромм уточняет содержание термина «воспитание» с позиции функционала социального процесса: «функция воспитания, очевидно, состоит в том, чтобы подготовить индивида к выполнению той роли, которую ему предстоит играть в обществе. То есть воспитание должно сформировать его характер таким образом, чтобы он приближался к социальному характеру, чтобы его собственные стремления совпадали с требованиями его социальной роли» [3, с. 289].

Признавая обусловленность системы воспитания в любом обществе фактором реализации указанной воспитательной функции, Э. Фромм исходит из того, что контуры и содержание системы воспитания членов общества вытекают из социальноэкономической структуры данного общества. При этом, методы воспитания следует воспринимать в качестве средств, с помощью которых комплекс социальных требований преобразуется в личные качества людей. По мнению ученого несмотря на то, что методы воспитания не являются причиной формирования определенного социального характера, они служат одним из механизмов формирования данного характера. В этом смысле, знание и понимание воспитательных методов может быть возведено в разряд важной составной части общего анализа каждого общества [3, с. 289-290].

Проводя параллель между воспитанием и манипуляцией, Э. Фромм выступает в качестве гуманиста, что может быть проиллюстрировано его суждением относительно необходимости веры в возможности других людей, в наши собственные возможности и в возможности человечества в целом. Согласно выводу ученого, воспитание тождественно помощи человеку в реализации его возможностей. Уточняя этимологию термина «воспитание», Э. Фромм замечает следующее: «Английское слово «воспитание» («education») происходит от латинского «е-ducere», буквально-вести вперед или делать явным нечто, наличествующее потенциально. Воспитание в этом смысле ведет к существованию («ехіstence»), которое буквально означает становление, выведение из состояния возможности в состояние проявленной реальности» [3, с. 525]. Что касается термина «манипуляция» как противоположного термину «воспитание», то 
в данном случае Э. Фромм придерживается следующей точки зрения: манипуляция основывается на отсутствии веры в развитие возможностей и на убежденности, что с человеком будет все в порядке, только если «вложить» в него все то, что желательно, и устранить то, что кажется нежелательным [3, с. 525].

Подвергая критике необихевиоризм американского психолога Б.Ф. Скиннера (1904-1990 гг.), психоаналитик Э. Фромм свидетельствует о наличии в век кибернетики (суть предтечи современного информационного общества) некоторых пределов действия воспитательного процесса на личность индивида: «В век кибернетики индивид все чаще становится объектом манипулирования. Его труд, потребление и свободное время-все находится под воздействием рекламы, идеологии и всего того, что Скиннер называет положительным стимулированием. Личность теряет свою активную ответственную роль в социальном процессе; человек становится совершенно «конформным» существом и привыкает к тому, что любое поведение, поступок, мысль и даже чувство, отклоняющееся от стандарта, будет иметь для него отрицательные последствия; он результативен лишь в том, что от него ожидают» [2, с. 53]. По мысли Э. Фромма, отмеченные обстоятельства нередко приводят к тому, что человеческое поведение не поддается объяснению, если его рассматривать как следствие исключительно только процессов обучения и воспитания [2, с. 85].

Уточняя соотношение воспитания и парадигмы общественных идеологем, Э. Фромм приходит к выводу об особой роли витальных интересов, первенствующее место в кругу которых занимает стремление к сохранению своей ценностной системы координат, а также ценностной ориентации, от которой зависит не только способность индивида к действию, но и осознание себя как личности. В случае обнаружения человеком идей, которые ставят под сомнение его собственные ценностные ориентации, он начинает ощущать угрозу своим жизненно важным интересам.

Таким образом, эмоциональное равновесие человека в значительной степени определяется как приемлемой для него ценностной системой координат, так и выбором соответствующих объектов почитания в виде ценностей, идеалов, предков, родителей, родины, класса, религии и иных объектов, к которым человек относится как к святыне. «Любое покушение на объект почитания вызывает такой же точно гнев со стороны индивида или группы, как если бы речь шла о покушении на жизнь»,-замечает Э. Фромм [2, с. 172].

Резюмируя изложенное, следует заметить следующее:

во-первых, признавая свою гуманную сущность в границах общества, с которым он себя идентифицирует, человек должен быть постоянным актором процесса воспитания и самовоспитания;

во-вторых, целеполагание воспитательной работы корреспондирует процессу подготовки человека к выполнению своей социально-значимой миссии, главным ориентиром для реализации которой должны выступать интересы общества, предопределяющие полноту воплощения персональных интересов каждого человека в отдельности;

в-третьих, проводя разграничение между процессами воспитания и манипулирования, следует осознать различие между воспитательным потенциалом свободного развития творческих и интеллектуальных качеств человека и манипулятивным стремлением заинтересованной стороны в подавлении личности, направляемой в «прокрустово ложе» идеологических заблуждений и нравственных тупиков.

$$
* * *
$$

1. Новичкова Г.А. Идеи Эриха Фромма о педагогической антропологии // NOTA BENE. - 2012. - № 3 (7). - C. $57-68$.

2. Фромм Э. Анатомия человеческой деструктивности. - М.: Республика, 1994. - 447 с.

3. Фромм Э. Бегство от свободы. Человек для себя. - М.: АСТ: АСТ МОСКВА, 2006. -571 с.

4. Фромм Э. Революция надежды. Избавление от иллюзий. - М.: Айрис-Пресс, 2005. - 352 с. 